\title{
ISOPHASIC PARASITISM IN PHORADENDRON PERREDACTUM (VISCACEAE)
}

\author{
Job KuIJT ${ }^{1}$ \\ University of Victoria, Department of Biology, Victoria, BC V8W 3N5, Canada. \\ ${ }^{1}$ Corresponding author: jkuijt@uvic.ca
}

\begin{abstract}
It is pointed out that the newly described Phoradendron perredactum Rzedowski \& Calderón exhibits an advanced type of growth behavior (isophasic parasitism) that also occurs in three other, unrelated groups of parasitic flowering plants.
\end{abstract}

Key words: isophasic parasitism, Phoradendron perredactum, Viscaceae.

\section{RESUMEN}

Se señala que el recién descrito Phoradendron perredactum Rzed. \& Calderón exhibe un tipo avanzado de comportamiento del crecimiento (parasitismo isofásico) que también existe en otros tres grupos no relacionados de fanerógamas parásitas.

Palabras clave: parasitismo isofásico, Phoradendron perredactum, Viscaceae.

It is scarcely an exaggeration that the discovery of Phoradendron perredactum Rzedowski \& Calderón (Viscaceae) is one of the most interesting ones in the general area of parasitic flowering plants (Rzedowski \& Calderón, 2011). The interest lies to some extent in the greatly reduced stature of the plant, but more especially in its growth pattern, which has also, quite independently, been achieved in at least three other groups of flowering plants.

The major fact that we need to recognize is that the shoot clusters in Fig. 1A of the protologue are not separate individuals but that, on the contrary, they have 
sprouted from a single, interconnected endophyte. This is immediately evident from the fact that they are equivalent in stature, and also from their spacing along the host branch. Fig. 1A shows, without a doubt, that $P$. perredactum exhibits what I many years ago called isophasic parasitism as found in several species of Arceuthobium (Viscaceae), including the A. minutissimum mentioned in the protologue. Three North American species, as mentioned below, are additional examples. Isophasic parasitism is the sort of growth behavior in which the longitudinal growth of the endophyte keeps pace with the longitudinal extension of the parasitized host branch and, in every known case, develops its first external shoots in completely predictable locations, especially at leaf scars or even in its leaf axils (Kuijt, 1960). This pattern, in turn, implies an endophytic association with the host's vascular system. On old host branches, this regular shoot-emergence pattern breaks down somewhat, or the production of shoots ceases altogether. Isophasic parasitism also involves the permanent invasion of the host apical meristem by the endophyte, and is associated with a special type of brooming or fasciation of the host (Kuijt, 1960; Lye, 2006). In other words, it represents a remarkable synchrony between the endophyte and shoot emergence - in a sense, the ultimate host-parasite physiological balance. In some literature, it has been referred to as systematic brooming, a term that has never seemed sufficiently accurate to me.

As mentioned above, Fig. 1A of the protologue surely indicates isophasic parasitism. It would be interesting to have more field observations of this very rare plant. What is the exact distribution of mistletoe shoots on the host? Is there any evidence of an abnormal, stunted, or even broom-like host response? Beyond that, of course, is the possibility of the endophyte's presence in the host's apical meristem that will need to be explored.

Isophasic parasitism has not been demonstrated previously in Phoradendron. However, two instances have been reported in P. bolleanum (Seem.) Eichler that are reminiscent (Kuijt, 2003, p. 30). As mentioned above, it is well known in several species of Arceuthobium (the North American A. americanum Nutt. ex Engelm., A. douglasii Engelm., and A. pusillum Peck, and the Himalayan A. minutissimum Hook.), but only on their most common hosts trees. Even more surprising is the fact that the same isophasic parasitism has evolved in two completely unrelated groups of parasitic plants. In the parasitism of Pilostyles haussknechtii Boiss. (Apodanthaceae) on Astragalus spp. (Fabaceae) in Syria and Iraq, a zonation of the emerging parasite flowers on host branches occurs as on isophasic Arceuthobium brooms. Even more remarkable is the fact that the parasite emerges only at the base of the host's petioles, one flower on each side, and that the shoot apex of the host contains 
the most distal portions of the endophyte. The remaining parallel is the Japanese plant Mitrastema yamamotoi Makino (Mitrastemonaceae) that parasitizes the roots of Quercus sp., where a definite zonation also occurs, the flowers emerging at a constant distance from the host's root apices. Here, also, a modification of the host growth occurs that allows the infected roots to grow horizontally, just below the soil surface. In this particular instance the presence of the endophyte in the host's apical meristems has not been demonstrated (Kuijt, 1960). In a sense, these several, independent cases of isophasic parasitism represent the most highly evolved mode of parasitism in the flowering plants.

\section{LITERATURE CITED}

Kuijt, J. 1960. Morphological aspects of parasitism in the dwarf mistletoes (Arceuthobium). Univ. Calif. Publ. Bot. 30: 337-436, pl. 34-48.

Kuijt, J. 2003. Monograph of Phoradendron (Viscaceae). Syst. Bot. Monogr. 66: 1-643.

Lye, D. 2006. Charting the isophasic endophyte of dwarf mistletoe Arceuthobium douglasii (Viscaceae) in host apical buds. Ann. Bot. 97: 953-963.

Rzedowski, J. \& G. Calderón de Rzedowski. 2011. Dos especies notables de Phoradendron (Viscaceae) de la Mixteca Oaxaqueña (México), una nueva y una complementada. Acta Bot. Mex. 96: 3-10. 